\title{
Learning from "Totto-chan: the Little Girl at the Window": An Educational Perspective from Japanese Author
}

\author{
Sadhya Permeiswari \\ SMA Negeri 2, Dumai. Indonesia \\ sadhyapermeiswari@gmail.com
}

\section{ARTICLE HISTORY \\ Received : 2019-06-23 \\ Revised : 2019-06-27 \\ Accepted : 2019-07-10}

\section{KEYWORDS}

Educational values

Totto-chan

Little girl at the window

Japanese author

\begin{abstract}
The novel "Totto-chan: The Little Girl at the Window" is a novel which some parts of its story reflects concept of education that is unique and different. The concept education in this novel related with educational value according to Moleong perspective. Therefore, this research is mainly purposed to search about what are the educational values found in Tottochan: The Little Girl at the Window"? and how educational values appear in "Tottochan: The Little Girl at the Window" based on Moleong perspective. This research is qualitative one by using content analysis method. Two data sources were chosen the primary data source is the novel itself and the secondary data are books, literature, official websites and other relevant materials. In general, the result found educational values contained in the novel based on Moleong perspective. By this research, it is expected that teachers can implement the positive things that exist in this study and in the novels at school and also encourage students' interest in literature.
\end{abstract}

\section{Introduction}

In 2008, Gramedia Publisher Main Library published a Japanese translation novel entitled "Tottochan" which was written by Tetsuko Kuroyanagi. Previously this novel had been published in its home country, Japan, in 1982. At the beginning of the publication of the novel it immediately became a best seller because in the period of a year it managed to sell 4.5 million novels. This phenomenal and inspirational novel also succeeded in stealing the attention of the Japanese government, especially in the field of education, which finally decided to make this novel a compulsory book for education and officially became one of the subject matters in school.

In general, literary works are beautiful and useful in other words in literature there are many values of education (education). Thus, literature aims to strengthen the value of education within oneself. A high-value literary work is a literary work that contains a high educational value, which elevates human dignity. literary works created by writers are not solely relying on talent and proficiency in expression, but more than that, a writer gives birth to literary works that also have a vision, mission, aspiration and struggle.

Totto-chan consists of 280 pages and 63 chapters. It is based on real events experienced by its author Tetsuko Kuroyanagi. This novel contains the personal experienced by Tetsuko Kuroyagi about her school as a child named Tomoe Gakuen, led by a school principal who was greatly admired by Tetsuko
Kuroyanagi named Sosaku Kobayashi. As the principal of Sosaku Kobayashi, he successfully applied the educational method that was liked by all of his students. The educational method stems from the principal's understanding that every child is born with a good character, which can easily be damaged due to their environment or due to the bad influence of adults. That's why Sosaku Kobayashi strives to find good character in every child and develop it so that children grow up to be adults with distinctive personalities. Sosaku Kobayashi strives to instill character education with his students so that they grow into children who know and recognize their talents and are able to develop them.

The novel "Totto-chan" is full of educational values. These educational values include attractive learning methods that are carried out in accordance with the interests and talents of each child. Children are also guided to be able to recognize and understand their personal character and be able to develop it optimally. Parents are invited to play an active role in being able to accompany their children and most importantly try to give their children trust. The educational value contained in the novel "Totto-chan" is also very relevant to the condition of education in Indonesia today which is developing the concept of character education.

Based on the background above, the study of the educational values contained in Tottochan's novel by Tetsukokuroyonagiper is necessary because it is full of educational values that are beneficial to life, thus elevating the dignity of the readers. 


\section{Methodology}

This review uses a qualitative decriptive form to understand which behavior, perceptions, motivations, actions, and others experienced by the research subject. The use of qualitative forms in this study is because this research has characteristics that are in accordance with the characteristics of qualitative research. While descriptive method research by collecting data in the form of words or sentences. The use of descriptive method because it is in accordance with the purpose, namely to describe the structure of the novel.

The technique used to collect this research data is an indirect technique with documentary studies, Collecting steps data with documentary techniques is carried out as follows.

a) Carefully read the contents of the novel

b) Identify the structure of the novel that is in accordance with the research problem and record it

c) Classify or group data according to research problems

d) Interpreting the data that has been collected in accordance with the research problem

e) Discuss the results of data collection with the supervisor

Steps were taken to analyze data with an approach hermeneutic.

i. Read intensively and critically the data that has been classified

ii. Analyze and interpret meaning; by finding words or sentences then linking those interpretations in a paragraph classified as meaning in the novel.

\section{Strengths of the Novel}

Toto-Chan is a young girl who has very high learning and creativity. He has a lot of potential and various questions, like most children. He has a high curiosity. Because of his many attitudes from asking and his actions which were considered quite dangerous, he was also expelled from school, even though at that time he was still in class 1 of elementary school. Toto-Chan's parents took the initiative to move Toto-Chan to Tamoe Gakuen.

Unlike most schools that determine the lessons that students must follow, in Tamoe Gakuen all students are free to determine what lessons they want to start. The principal at Tamoe Gakuen wants to listen to what his students want to say. At Tamoe Gakuen all students are free to guide them to develop their ability.
Kobayashi instills confidence in children to solve their own problems, such as when a tottochan wallet falls into the toilet, then takes all the dirt to the surface with a dipper. He did have a reason that he wanted to take his wallet that had fallen in the sink, he wanted to find out and peek into the dark hole of the toilet. Maybe if someone else saw what Tottochan was doing would be angry or even punish. But not with Kobayashi when he passed that place, not anger or punishment received by Tottochan but rather friendly and calm words like the following quote: "You will return everything if it's done right? "(Page 57). Getting a good response from Kobayashi as in the above quote, Tottochan then put the dirt back into the hole, also inserted the wet soil, then leveled the ground, closed the hole neatly and returned the dipper borrowed from the gardener's warehouse. Another satisfaction tottochan feels is the trust given by the principal by not scolding him. As seen in the following quote:

"But Tottochan doesn't care. He was satisfied because he had mobilized all his abilities to find the wallet. Tottochan's satisfaction was the result of the confidence that the headmaster instilled by believing it and not scolding him. But of course it was too complicated for Tottochan to understand at the time "(Page 71). In the quote above, Kobayashi's teacher wants to teach his students (tottochan) about his social relationships with other people either at school or in the community if he later grows up, that whoever our friends is we must still love our friends even though he has limitations (disabilities) . Kobayashi's teacher also teaches that a student must not demean other people who have deficiencies. This makes students in Tomoe love and love each other. So that social relations such as friends will be well interwoven without dropping each other and humbling.

The atmosphere at Tamoe Gakuen is different from other schools which are built with tall buildings and press many lessons to each of their students. At Tamoe Gakuen classrooms consist of train cars that are no longer used to create a fresh atmosphere every time there.

Mr. Kabayashi as the principal there applies a different curriculum. All guardians and parents of students support each action from Mr. Kabayashi as the principal there. Because the entire curriculum provided is very good for improving the ability of his students. Unfortunately, all the memories and learning of Toto-Chan had to end when the bomb detonated the Tamoe Gakuen school in 1945 when Japan experienced bombing by America, because at that time Japan was experiencing World War II. Causing huge losses for Japan. At that time all students and instructors at Tamoe-Gakuen felt devastated, the building suffered severe damage as a result of this bomb blast. 
All Japanese citizens were discouraged and then evacuated. And all students of Tamoe Gakuen hope that after all this has happened all will return to normal.

The skin of this novel book is thick enough to have long durability / not easily damaged. Readers can also imagine each incident in detail because in each chapter there are supporting illustrations that are easy to understand. Although the novel was first published in 1981 the language used was very easy for the reader to understand, besides that there were additional explanations on several unfamiliar Japanese terms in the ears of outsiders, as in this excerpt "Totto-chan's class decided to perform kanjincho (fundraising agreement) ". Unfortunately, the book's skin does not attract the attention of readers and in some chapters it seems boring, as in the chapter "Braid Hair". In that chapter only tells the first time Totto-chan has her hair braided.

This novel, which consists of 63 short chapters, is very important to read especially for teachers. This novel provides an overview of some students in the world who are bored with conservative learning in schools in general. Describe students who are bored with all required subjects according to the curriculum. The learning system in Tomoe that frees all lessons makes students able to focus on getting stuck on just one lesson, so there is no element of coercion in learning. In addition, learning activities are sometimes outdoors, making students receive lessons not from books but also from nature and the surrounding environment. The most impressive thing is that there is no teacher or several schools that have actions such as scolding students or the emergence of selfish teacher traits, even for acts as strange as Totto-chan's when searching for his wallet at the school's disposal site, only compassion and wisdom received by students. This novel inspires teachers to develop education not only the material provided, but better practice in life and to better understand the characteristics of students, especially to understand children who begin to develop their knowledge.

During school at Tomoe Totto-chan many progress in him. Totto-chan's attitude and behavior improved day by day. Totto-chan grew up to be a child who was confident, creative and never gave up and had many friends who cared about each other. Even though Tottochan's friends at Tomoe's school had received it well, he still did strange things like at school. The teachers in Tomoe also consider a lot of Totto-chan's behavior to be difficult to understand. The behavior of the main characters in this novel is interesting to study because the main character Tottochan's behavior is different from most children in general.
In addition, the teacher at the school also considers Totto-chan a child who likes to do strange things. Totto-chan is a child in development. The period of development can be analyzed by psychological theory. Therefore, it takes help from psychological theory to analyze the psychology of the characters contained in literary works and to find out more about the intricacies of human actions.

In this novel, there are words that make us inspired to be passionate about living our lives as educators. Plus the use of language that is easy to understand and the placement of time and place settings that are very detailed. Each chapter has only a few pages, making it easier for readers to read and not bring boredom to the reader.

The novel also illustrates the importance of longsighted friendship, such as friendship with Yasuaki who is a polio sufferer and learns language, culture, and life in America with Miyazaki, who at that time Japan was having bad relations with America. The meaning of friendship can even be taken from Tottochan's relationship with his dog, Rocky.

This inspirational novel is very suitable to read for students, parents, teachers, and people who are involved in the field of education.

From this novel, we can conclude that in the teaching and learning process in the education of primary school age children different from middle school-age children. Primary school students prefer to study with different methods. That is commonly called playing while learning. Elementary students enjoy the fun and not monotonous learning method.

We can follow the example of Tomoe Gakuen in this novel that allows students to learn according to their interests and abilities. Every student must have their own pleasure that they can develop early on. But the necessity to learn basic subjects such as Language Mathematics and science can be applied in different and fun methods so that students are not bored with the material given. After that students may take part in activities that they enjoy such as playing dancing or sports music.

In this book there are many philosophies and teachings of life, many inspire good learning patterns applied, the topics in this novel are very good, the language used in this novel is very easy to understand and very good, this book is a compulsory book for education in Japan and this novel makes history in the Japanese publishing world because of 4,500,000 books a year. 


\section{Weaknesses of the Novel}

Of the many advantages that exist, this novel also has drawbacks. One of them is there are words that are difficult to understand so we need the help of a dictionary to enjoy reading this novel.

This book is targeted to contribute to educators, as well as students. Especially for the elementary school level. As a result, for adult readers, maybe the stories delivered are too light or less exciting. The page per chapter averages too short so that sometimes it doesn't feel its deep emotions.

\section{Results}

Based on the results of the reading it is known that the educational values contained in the "Totto-chan" novel by Tetsuko Kuroyanagi include religious values, socio-cultural values, moral values, and intellectual values. The religious values contained in this novel include: Praying (Mama prayed solemnly, hoping that this time everything will go smoothly), grateful (Mama is grateful that Totto-chan seems to enjoy her school), is responsible for religion (we go to the temple goes to Kuhonbotsu, then the children gather and walk around the temple courtyard), worship (Sengkuji temple is smaller than Kohunbotsu Temple. He considers the place sacred. Solemnly bows respectfully), celebrates religious holidays (Mama and Totto-chan look happy following a celebration day to honor the Goddess of music and beauty, Benten).

Socio-cultural values are also one of the values of education found in the "Totto-chan" novel by Tetsuko Kuroyanagi. The excerpts of data on socio-cultural values include caring for each other (in fact, there are not enough words to express the principal's lo ve for students and school, but the children are not old enough to realize it), establish friendship (Totto-chan has met and made friends with all the children in his class. He feels like he has known them for a long time), deliberation (the carriage comes very late. After all the other trains are not operating. Who really wants to see them must go home first and ask permission from parents, if you want, you can come back with pajamas and blankets and have dinner).

The moral values contained in the "Totto-chan" novel include a polite attitude (while bowing respectfully, Totto-chan asked eagerly, "What is this father? Principal or station head?), Eager to do everything (for a moment then, Totto-chan screamed with joy then stood up and ran towards the train school. He looked back and shouted to Mama. Come on, hurry up! Hurry up! Let's take the motionless train), have an attitude of sympathy (because there are no defects in his body, of course he wouldn't mind being asked like that, but Takahashi has stopped growing and the child knows, that's why the headmaster has designed all sports day activities specifically so that Tabahashi can participate well), advise one another (these cars are dank class If you really want to ride this train, you have to be sweet and polite in front of the headmaster, now we will face the head a school. If you are polite and kind, maybe you will be accepted at this school), respect each other (Mama imagined Totto-chan cheerfully opening and closing her new desk. Mama didn't think that was a mischievous thing. After all, Totto-chan would have succeeded if already bored), an attitude of restraint / self-control (playing a song, said Totto-chan. The small group, which usually passes through a loud clarinet, a gong, drum, and a samisen of a Japanese stringed instrument. Poor teacher is just can wait patiently until the noise is over), have a brave attitude (the headmaster tells Totto-chan to sit down and turn to mama, you can go home now. I want to talk to Totto-chan. For a moment Totto-chan feels bad, but somehow she feel like it will suit him), honestly (when he said Totto-chan could tell what he wanted to tell. Totto-chan was happy and immediately spoke excitedly. Cherries asked chaotic and the order is not known, but all said what it is), kind (mama had a lot of work to be done). He is busy filling the lunch box with something from the sea and something from the mountains. While giving breakfast to Totto-chan. Mama also entered the abnormality ticket of the Totto-chan train into a plastic wallet that would be wrapped around Totto-chan's neck with a rope so that it wouldn't disappear, a helpful attitude (Yasuaki's arms and legs were very weak. Apparently she couldn't go up to the first step without help. -chan quickly descends and pushes Yasuaki from below).

While the value of education in the form of intellectual value can be seen from the ability to negotiate and invite other people to work together (the ticket collection officer looks at it for the first time. My son also wants to work at the church station. Maybe later you can work together. Hemmmm, Tottochan scrambled around and considered the idea seriously. I don't mind working with your child. I will think about it later. But now I'm busy because I want to go to my new school), able to solve the problem (obviously you have to do something to solve the problem, this is unfair for other students, you have to look for other schools, schools that can understand and teach their little ones to adjust to others), are able to think accurately, have certainty of purpose, and ability educate (should he show them the train ticket? Totto-chan thought. But he did not want to be late, because it was decided to abandon his intention that day and hurry away).

Educational values contained are educational values that are able to provide inspiration for readers to understand the various values of emerging education that can be realized in everyday life. Among some of the educational values that appear in 
the "Totto-chan" novel religious values and moral values are the most widely discussed educational values by the author. Religious values and moral values are closely related to the existence of sociocultural values and intellectual values.

\section{Conclusion}

Totto chan is a child who is passionately entering elementary school, but at the first school the totto chan was released because of his attitude which was sometimes considered strange by his teacher. His habits such as looking out the window lingered, waiting for a group of street musicians, opening the table over and over again and again over and over making patience, the teacher. Finally Mom Totto Chan decided to find another school that could accept Totto Chan.

After being expelled from school, Totto-chan was registered by her mother to Tomoe's school (Tomoe Gakuen). At his new school Totto-chan felt very happy. That was because what he lived in Tomoe was very different from his old school, maybe even other schools at that time. In Tomoe, students study on the train cars that are used as a class, so Totto-chan and his friends can learn while enjoying the scenery outside the carriage and imagine traveling. In addition, in Tomoe students are allowed to change the order of the lessons according to their wishes. These things make the school unique.

In Tomoe, Totto-chan not only learns about academic lessons, but also learns about the values of life, such as about friendship, respect, respect and respect for others and the freedom to be yourself. Even though he may not have realized it. Totto-chan experienced various stories and stories in her daily life in Tomoe Gakuen, of course also with the innocence she had.

The education system in Tomoe Gakuen is very different from other conventional schools. There, students may change the order of lessons according to their interests. Some start learning physics, some choose to draw, some want to learn the language first, basically free. Not infrequently also the principal invited the students to take a walk while explaining what they saw while walking. Unnoticed by students, they have learned many things, in a very pleasant way. Never before has Totto-chan felt as excited as he was at school. He felt at home at Tomoe Gakuen. Aside from the pleasant way of learning, he also has many friends and principals who love all students. Tottochan who was once considered naughty turned out to be a good child. This can be seen from how much he loved his friends, some of whom had physical disabilities.

We can conclude that the teaching and learning process in primary school-age children is different from middle school-age children. Primary school students prefer to study with different methods. That is commonly called playing while learning. Elementary students enjoy the fun and not monotonous learning method.

In the Indonesian Primary School education curriculum apply learning in accordance with what has been set in the curriculum. The students inevitably like to or not have to follow all the lessons that maybe some of them think the lesson is not interesting or even stressful. This makes the learning spirit of the elementary school students decline.

We can follow the example of Tomoe Gakuen in this novel that allows students to learn according to their interests and abilities. Every student must have the pleasure they can develop early on. But the necessity to learn basic subjects such as Language Mathematics and science can be applied in different and fun methods so that students are not bored with the material given. After that, students may take part in activities they enjoy such as playing dancing or sports music.

The educational values consist inTotto Chan: A Little Girl at The Window novel are educational values. The majority of existing educational values derived from the headmaster and Tomoe Gakuen school, while others emerged from Totto Chan's family and the people who have ever encountered with Totto Chan.From the educational values were found in Totto Chan: A Little Girl at the Window, the researcher found educational values which are suitable with the Moleong perspective about education. There are educational values that suitable with the concept of liberating education.

\section{References}

Adeney Risakota, Bernhar. Pendidikan Kritis Yang Membebaskan dalam Basis. Nomor 01-01 Tahun ke- 50, Januari-Februari, 2001.

Collie, Joanne, and Stephen Slater. Literature in the Language Classroom: A Resource Book of Ideas and Activities. Cambridge: Cambridge University Press, 1987.

Dale, John, and Emery J. Hyslop- Margison. Paulo Freire: Teaching for Freedom and Transformation: The Philosophical Influences on the Work of Paulo Freire. Berlin: Springer Science \& Business Media, 2010.

Freire, P. (1973). Education for critical consciousness (Vol. 1). Bloomsbury Publishing

Freire, Paulo. Cultural Action for Freedom. Massachusetts: Harvard Educational Review and Centre for Study of Development and Social Change, 1970. 
Halstead, Mark, and Monica J. Taylor. Values in Education and Education in Values. London: Routledge, 2005.

Haydon, Graham. Values for Educational Leadership. London: Sage Pulications, 2007.

Henry Hudson, William. An Introduction to the Study of Literature. 2 nd Ed. London: Enlarge publisher, 1913.

Kuraedah, S., Gunawan, F., Wekke, I. S., \& Hamuddin, B. (2018, July). Learning Environment Construction in Islamic Higher Education: Connecting the Puzzles of Ideas. In IOP Conference Series: Earth and Environmental Science (Vol. 175, No. 1, p. 012107). IOP Publishing.

Natia, I.K. Apresiasi Sastra Indonesia. Surabaya: Bintang Surabaya, 2010.

Schipani, Daniel. "Liberation Theology and Religious Education" dalam Theologies of Religious Education (ed. Randolph Crumph Miller; Birmingham: Religious Education, 1996.

Smith, A., William. Conscientizacou Tujuan Pendidikan Paulo Freire. Terj. Agung Prihantoro. Yogyakarta: Pustaka Pelajar, 2001.

Susetyo, B. (2005). Politik pendidikan penguasa. LKIS PELANGI AKSARA.

Undang-Undang Nomor 20 tahun 2003 tentang Sistem Pendidikan Nasional. (Jakarta: Arta Duta Mas, 1994), article I verse 3.

Wekke, I. S., Ashrori, M., \& Hamuddin, B. (2018). Institutional Transformation of Madrasa of Muslim Minority in Thailand. Jurnal Pendidikan Islam UIN Sunan Gunung Djati, 4(1), 15-26.

Wekke, I. S., Yandra, A., \& Hamuddin, B. (2017, December). Learning Strategy in Class Management: A Reflection from Manado Case. In IOP Conference Series: Earth and Environmental Science (Vol. 97, No. 1, p. 012053). IOP Publishing.

Zaim El Mubarak. Membumikan Pendidikan Nilai. Bandung: Alfabeta, 2008. 